\title{
ЕНДОГЕННА ІНТОКСИКАЦІЯ ОРГАНІЗМУ ПІДДОСЛІДНИХ ТВАРИН ПРИ УРАЖЕННІ ПОРОЖНЬОЇ КИШКИ ЗА УМОВ ПОСТРЕЗЕКЦИЙНОЇ ПОРТАЛЬНОЇ ГІПЕРТЕНЗІї
}

Вступ. Видалення великих об'ємів паренхіми печінки може супроводжуватися виникненням пострезекційної портальної гіпертензії. Остання призводить до морфологічної перебудови органів басейну ворітної печінкової вени, ураження їх структур, зростання ендогенної інтоксикації, яку при пошкодженнях порожньої кишки у названих патологічних умовах досліджено недостатньо.

Мета дослідження - вивчити особливості ендогенної інтоксикації організму піддослідних тварин при ураженні порожньої кишки за умов пострезекційної портальної гіпертензії.

Методи дослідження. Дослідження проведено на 60 білих щурах-самцях, яких поділили на 4 групи: 1-ша нараховувала 15 інтактних тварин; 2-га - 15 щурів, у яких було видалено 31,5 \% паренхіми печінки; 3-тя - 15 тварин, в яких видалили 42 \% паренхіми печінки; 4-та - 15 шурів після резекції 58,1 \% паренхіми печінки. Евтаназію піддослідних тварин здійснювали шляхом кровопускання за умов тіопенталового наркозу через місяць від початку експерименту. Стан ендогенної інтоксикації оцінювали за концентрацією в сироватці крові ТБК-активних продуктів, визначенням окисної модифрікації білків, вмістом молекул середньої маси. Гістологічні препарати з порожньої кишки фрарбували гематоксилін-еозином, за ван-Гізон, Маллорі, Вейгертом, толуїдиновим синім. Гістостереометрично визначали відносні об'єми пошкоджених епітеліоцитів, м'язових клітин, ендотеліоцитів. Кількісні величини обробляли статистично.

Результати й обговорення. У щурів через місяць після резекції 42 та 58,1 \% паренхіми печінки спостерігали розширення печінкової ворітної вени, повнокров'я і розширення брижових вен та видимого венозного русла тонкої і товстої кишок. Виявлені зміни свідчили про наявність портальної гіпертензії. Слизова оболонка порожньої кишки повнокровна, набрякла, з поодинокими осередками точкових крововиливів. У стінці порожньої кишки виявили дистрофрію, некробіоз епітеліоцитів, міоцитів, ендотеліоцитів, стромальних структур, інфрільтративні та склеротичні процеси, які були більш виражені при резекції 58,1 \% паренхіми печінки. Відносні об'єми пошкоджених досліджуваних структур значно зросли через місяць після резекції 42 \% паренхіми печінки і найбільших величин досягли при видаленні 58,1 \% об'єму даного органа, вказуючи на виражене ураження порожньої кишки в змодельованих експериментальних умовах. При виявленому ураженні порожньої кишки суттєво зросла ендогенна інтоксикація організму, що підтверджувалося достовірним (p<0,05) збільшенням вмісту молекул середньої маси в сироватці крові, ТБК-активних продуктів, окисномодифрікованих білків. Ступінь ендогенної інтоксикації організму при пострезекційній портальній гіпертензії залежав від вираження ураження порожньої кишки.

Висновки. Резекція великих об'ємів паренхіми печінки призводить до розвитку пострезекційної портальної гіпертензії, пошкоджень структур порожньої кишки та ендогенної інтоксикації організму, яка супроводжується збільшенням вмісту молекул середньої маси, окисномодифрікованих білків, активацією пероксидного окиснення ліпідів. Ступінь ендогенної інтоксикації організму залежить від видаленого об'єму паренхіми печінки та вираження пошкоджень структур порожньої кишки.

КЛЮЧОВІ СЛОВА: ендогенна інтоксикація; порожня кишка; пострезекційна портальна гіпертензія.

ВСТУП. Видалення великих об'ємів паренхіми печінки, яке проводять при доброякісних та злоякісних пухлинах, метастазах, травмах печінки, внутрішньопечінковому холангіолітіазі, альвеолярному ехінококозі, трансплантації печінки, може супроводжуватися виникненням пострезекційної портальної гіпертензії [1, 2]. Остання призводить до тяжких ускладнень: кровотечі 3 (c) А. Г. Шульгай, Л. В. Татарчук, М. С. Гнатюк, 2018. варикозно розширених вен стравоходу і шлунка, прямої кишки, асциту, спленомегалії, вторинного гіперспленізму, паренхіматозної жовтяниці, портосистемної енцефалопатії, печінкової недостатності $[1,3,4]$. Пострезекційна портальна гіпертензія супроводжується також морфологічною перебудовою органів басейну ворітної печінкової вени, ураженням їх структур, зростанням ендогенної інтоксикації, яку при пошкодженнях 
тонкої кишки у названих патологічних умовах досліджено недостатньо [5].

Мета дослідження - вивчити особливості ендогенної інтоксикації організму піддослідних тварин при ураженні порожньої кишки за умов пострезекційної портальної гіпертензії.

МЕТОДИ ДОСЛІДЖЕННЯ. Дослідження проведено на 60 лабораторних статевозрілих білих щурах-самцях, яких поділили на 4 групи: 1-ша нараховувала 15 інтактних тварин; 2-га - 15 щурів, у яких було видалено 31,5 \% паренхіми печінки; 3-тя - 15 тварин, в яких видалили 42 \% паренхіми печінки; 4-та - 15 щурів після резекції 58,1 \% паренхіми печінки [6]. Щури перебували в умовах віварію на звичайному раціоні. За тваринами постійно наглядали. Їх регулярно зважували, спостерігали за активністю, апетитом, шерстю. Хворих щурів для експериментальних досліджень не використовували. Евтаназію піддослідних тварин здійснювали шляхом кровопускання за умов тіопенталового наркозу через місяць від початку експерименту. Всі маніпуляції та евтаназію щурів проводили 3 дотриманням основних принципів роботи з експериментальними тваринами відповідно до положення Європейської конвенції про захист хребетних тварин, що використовуються для дослідних та інших наукових цілей (Страсбург, 1986), Загальних етичних принципів експериментів на тваринах, ухвалених на Першому національному конгресі з біоетики (Київ, 2001), а також Закону України "Про захист тварин від жорстокого поводження" (від 21.02.2006) [7]. Стан ендогенної інтоксикації оцінювали за концентрацією в сироватці крові ТБК-активних продуктів [8, 9], визначенням окисної модифрікації білків [10], вмістом молекул середньої маси [11].

Вирізані шматочки з порожньої кишки фріксували в $10 \%$ нейтральному розчині фрормаліну і після відповідного проведення через етилові спирти зростаючої концентрації заливали в парафрінові блоки за загальноприйнятою методикою. Гістологічні зрізи товщиною 5-7 мкм після депарафрінізації фрарбували гематоксилін-еозином, за ван-Гізон, Маллорі, Вейгертом, толуїдиновим синім [12]. Гістостереометрично визначали відносні об'єми пошкоджених епітеліоцитів
(ВОПЕп), м'язових клітин (ВОПМ), ендотеліоцитів (ВОПЕн) [6, 13]. Морфометричні виміри проводили за допомогою світлового мікроскопа "Olimpus BX-2" із цифровою відеокамерою і пакетом прикладних програм "Відео Тест 5,0" та “Відео розмір 5,0". Кількісні величини обробляли статистично. Обробку результатів виконано у відділі системних статистичних досліджень Тернопільського державного медичного університету імені І. Я. Горбачевського в програмному пакеті Statsoft STATISTICA. Різницю між порівнюваними величинами визначали за критеріями Манна-Уїтні та Стьюдента [14].

РЕЗУЛЬТАТИ Й ОБГОВОРЕННЯ. У ПІДдослідних тварин через місяць після резекції 42 та 58,1 \% паренхіми печінки при розтині очеревинної порожнини спостерігали розширення печінкової ворітної вени, повнокров'я і розширення брижових вен та видимого венозного русла тонкої і товстої кишок. Слизова оболонка порожньої кишки повнокровна, набрякла, з поодинокими осередками точкових крововиливів. Описане вище свідчило про наявність пострезекційної портальної гіпертензії. Остання більш вираженою виявилася при резекції 58,1 \% паренхіми печінки.

При світлооптичному дослідженні мікропрепаратів порожньої кишки у 3-й та 4-й групах спостережень виявили виражені судинні розлади (повнокров'я переважно венозних судин, явища перивазального набряку, стази, тромбози у венозній частині мікрогемоциркуляторного русла, осередки діапедезних крововиливів), дистрофрічні, некробіотичні зміни епітеліоцитів, міоцитів, ендотеліоцитів судин, стромальних структур, інфрільтративні та склеротичні процеси. Домінували описані патогістологічні зміни у стінці порожньої кишки при резекції 58,1 \% паренхіми печінки. Наведене підтверджувалося досліджуваними морфометричними параметрами структур порожньої кишки (табл. 1). Вказані морфометричні параметри демонструють наявність значної кількості пошкоджених епітеліоцитів слизової оболонки порожньої кишки, міоцитів ії̈ м'язової оболонки та ендотеліоцитів судинного русла. Відносні об'єми пошкоджених досліджуваних структур значно зросли через місяць

Таблиця 1 - Морфометричні параметри структур порожньої кишки

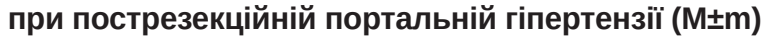

\begin{tabular}{|c|c|c|c|c||}
\hline \hline \multirow{2}{*}{ Параметр, \% } & \multicolumn{4}{|c|}{ Група спостереження } \\
\cline { 2 - 5 } & 1-ша & 2-га & 3-тя & 4-та \\
\hline ВОПЕп & $2,12 \pm 0,03$ & $5,60 \pm 0,04^{\star \star \star}$ & $38,90 \pm 0,54^{\star \star \star}$ & $26,80 \pm 1,20^{\star \star \star}$ \\
\hline ВОПМ & $1,90 \pm 0,03$ & $2,40 \pm 0,06^{\star}$ & $12,30 \pm 0,27^{\star \star \star}$ & $20 \pm 0,48^{\star \star \star}$ \\
\hline ВОПЕн & $2,15 \pm 0,03$ & $4,85 \pm 0,06^{\star \star \star}$ & $19,40 \pm 0,45^{\star \star \star}$ & $45,90 \pm 0,63^{\star \star \star}$ \\
\hline
\end{tabular}

Примітка. Тут і в таблиці 2: * - p<0,05; *** - p<0,001 порівняно 3 1-ю групою. 
після резекції 42 \% паренхіми печінки і найбільших величин досягли при видаленні 58,1 \% об'єму даного органа, вказуючи на виражене ураження порожньої кишки в змодельованих експериментальних умовах.

Досліджували біохімічні показники: окисномодисріковані білки (ОМБ), ТБК-активні продукти (ТБК-АП), молекули середньої маси (МСМ) (табл. 2). Під час усестороннього аналізу вказаних величин встановлено, що процеси окисної модифікації білків у сироватці крові щурів при резекції 31,5 \% паренхіми печінки майже не змінювалися порівняно з контролем, при видаленні $42 \%$ паренхіми печінки вони статистично достовірно ( $<<0,001)$ зросли в 6,3 раза, а при резекції 58,1 \% об'єму печінки - у 7,2 раза.

Рівень у сироватці крові ОМБ реєстрували при довжині хвилі 370 нм. Процеси окисної модисрікації білків аналогічно змінювалися при довжині хвилі 430 нм. При цьому в 2-й групі спостережень вони майже не змінювалися, при видаленні 42 \% паренхіми печінки збільшилися в 4,8 раза, а при резекції 58,1 \% паренхіми печінки - у 7,2 раза.

Підвищення активності окисних процесів в організмі при змодельованій патології можна пояснити збільшенням токсичного впливу, який зумовлений пошкодженням структур порожньої кишки при пострезекційній портальній гіпертензії. Спостерігали також виражене зростання рівня ТБК-активних продуктів у сироваткі крові при видаленні 42 \% паренхіми печінки. При цьому вміст ТБК-АП статистично достовірно $(p<0,05)$ збільшився на 7,9 \%, а за резекції 58,1 \% паренхіми печінки - на 47,4 \%, що свідчило про зростання інтоксикації організму, яка залежала від видаленого об'єму паренхіми печінки та ступеня ураження тонкої кишки, що відіграє важливу роль у детоксикації. Відомо, що надмірне накопичення продуктів пероксидного окиснення ліпідів в організмі призводить до пошкодження мембранних ліпідів, ліпопротеїнів і білків, інактивації фрерментів, змін структурно-фрункціональної організації мембран та їх проникності [15].

Вміст МСМ у сироватці крові при реєстрації їх довжиною хвилі 254 нм у 3-й групі спостережень виявився статистично достовірно $(p<0,05)$ збільшеним на 14,3 \%, а в 4-й групі - у 2,4 раза. При визначенні даного показника довжиною хвилі 280 нм він, відповідно, підвищився на $25 \%$ та у 3,6 раза. Отримані дані свідчать про те, що вміст молекул середньої маси як маркерів ендогенної інтоксикації найбільшою мірою зріс через місяць після видалення 58,1 \% паренхіми печінки, що призвело до розвитку пострезекційної портальної гіпертензії, вираженого венозного повнокров'я, гіпоксії, дистрофії, некробіозу епітеліоцитів, міоцитів, ендотеліоцитів, стромальних структур, інорільтративних і склеротичних процесів у стінці порожньої кишки. Ступінь ендогенної інтоксикації організму залежить від вираження ураження порожньої кишки при пострезекційній портальній гіпертензії, тобто зі збільшенням кількості структур вказаного органа, втягнутих у патологічний процес, зростає ендогенна інтоксикація організму.

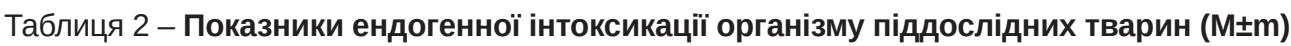

\begin{tabular}{|c|c|c|c|c|}
\hline \multirow{2}{*}{ Показник } & \multicolumn{4}{|c|}{ Група спостереження } \\
\hline & 1-ша & 2-га & 3-тя & 4-та \\
\hline ОМБ, ммоль/г білка (370 нм) & $0,610 \pm 0,012$ & $0,620 \pm 0,015$ & $3,90 \pm 0,06^{\star \star \star}$ & $4,45 \pm 0,07^{\star \star \star}$ \\
\hline ОМБ, ммоль/г білка (430 нм) & $0,250 \pm 0,003$ & $0,300 \pm 0,004$ & $1,200 \pm 0,018^{\star \star \star}$ & $1,800 \pm 0,021^{\star \star \star}$ \\
\hline Вміст ТБК-АП, мкмоль $\cdot л^{-1}$ & $6,58 \pm 0,12$ & $6,65 \pm 0,12$ & $7,10 \pm 0,15^{\star}$ & $9,70 \pm 0,18^{\star \star \star}$ \\
\hline МСМ, екстинція проб (254 нм) & $0,063 \pm 0,002$ & $0,066 \pm 0,003$ & $0,072 \pm 0,003^{*}$ & $0,150 \pm 0,003^{\star \star \star}$ \\
\hline МСМ, екстинція проб (280 нм) & $0,0440 \pm 0,0003$ & $0,0460 \pm 0,0003$ & $0,055 \pm 0,003^{*}$ & $0,160 \pm 0,005^{\star \star \star}$ \\
\hline
\end{tabular}

ВИСНОВКИ. Резекція великих об'ємів паренхіми печінки призводить до розвитку пострезекційної портальної гіпертензії, пошкоджень структур порожньої кишки та ендогенної інтоксикації організму, яка супроводжується збільшенням вмісту молекул середньої маси, окисномодифікованих білків, активацією пероксидного окиснення ліпідів. Ступінь ендогенної інтоксикації організму залежить від видаленого об'єму паренхіми печінки та вираження пошкоджень структур порожньої кишки.

Перспективи подальших досліджень. Всебічне вивчення ендогенної інтоксикації організму при пострезекційній портальній гіпертензії дозволить істотно покращити її діагностику, корекцію та профілактику. 


\section{СПИСОК ЛІТЕРАТУРИ}

1. Вишневский В. А. Сегментарные резекции, отдаленные результаты при злокачественных опухолях печени / В.А.Вишневский, М. Г. Ефанов, И.В.Казаков // Укр. журн. хірургії. - 2012. - № 1 (16). - С. 5-15.

2. Rialon K. L. Impact of screening for hepatic hemangioma in patients with multiple cutaneous infantile hemangiomas / K. L. Rialon, R. Murillo, R. O. Fevurtly // Pediatr. Dermatol. - 2015. - 32 (6). - P. 162-167.

3. de Franchis R. Revising consensus in portal hypertension: report of the Baveno $\mathrm{V}$ consensus workshop on methodology of diagnosis and therapy in portal hypertension / R. de Franchis, V. F. Baveno // J. Hepatol. 2010 - 53, No. 4. - P. 762-768.

4. Paravecino M. Major hepatic resection for hepatocellular carcinoma with or without portal vein embolization: Perioperutive outcome and survival // M. Paravecino, I. S. Chun, D. C. Madoff // Surgery. - 2009. - 145, No. 4. - P. $399-405$.

5. Sawada K. Multiple portal hypertensive polyps of the jejunum accompanied by anemia of the unknown origin / K. Sawada, T. Ohtake, N. Veno // Gastrointest. Endosc. - 2011. - 73. - P. 179-182.

6. Гнатюк М. С. Морфометрична оцінка особливостей ремоделювання структур дванадцятипалої кишки при резекції різних об'ємів печінки / М. С. Гнатюк, Л.В.Татарчук, О. Б. Ясіновський // Наук. вісн. Ужгород. ун-ту. Серія "Медицина". - 2016. - Вип. 1 (53). C. 92-95.

7. Резников О. Г. Загальні етичні принципи експериментів на тваринах / О. Г. Резников // Ендокринологія. - 2003. - 8, № 1. - С. 142-145.
8. Стальная И. Д. Метод определения малонового альдегида с помощью тиобарбитуровой кислоты / И. Д. Стальная, Т. Г. Гаришвили // Современные методы в биохимии. - М. : Медицина, 1977. - С. 66-68.

9. Мещишен І. Ф. Метод визначення окислювальної модифікації білків плазми (сироватки) крові / І. Ф. Мещишен // Буковин. мед. вісн. - 1998. - № 1. C. 156-158.

10. Арчаков А. И. Модисрикация белков активным кислородом и их распад / А. И. Арчаков, И. М. Михосоев // Биохимия. - 1998. - 54, № 2. - С. 179-186.

11. Корякина Е. В. Молекулы средней массы как интегральный показатель метаболических нарушений / Е. В. Корякина, С. В. Белова // Клинич. и лаб. диагностика. - 2004. - № 3. - С. 3-8.

12. Сорочинников А. Г. Гистологическая и микроскопическая техника / А. Г. Сорочинников, А. Е. Доросевич. - М. : Медицина, 2007. - 448 с.

13. Автандилов Г. Г. Основы количественной патологической анатомии / Г. Г. Автандилов. - М. : Медицина, 2002. - 240 с.

14. Лапач С. Н. Статистические методы в медикобиологических исследованиях Excell / С. Н. Лапач, А. В. Губенко, П. Н. Бабич. -К. : Морион, 2001. -410 с.

15. Ліснянська Н. В. Роль оксидативного стресу в патогенезі хронічного ентероколіту на фроні експериментального стрептозотоцинового діабету / Н. В. Ліснянська // Мед. та клініч. хімія. - 2017. - 19, № 1 (70). - С. 53-59.

\section{REFERENCES}

1. Vishnevskiy, V.A., Yefanov, M.G., \& Kazakov, I.V. (2012). Segmentarnyye rezektsyi, otdalennyye rezultaty pri zlokachestvennykh opukholyakh pecheni [Segmentar resection, long-term results in malignant liver tumors]. Ukr. Zhurnal Khirurgii - Ukrainian Journal of Surgery, 1 (16), 5-15 [in Ukrainian].

2. Rialon, K.L., Murillo, R., \& Fevurtly, R.O. (2015). Impact of screening for hepatic hemangioma in patients with multiple cutaneous infantile hemangiomas. Pediatr. Dermatol., 32 (6), 162-167.

3. de Franchis, R., \& Baveno, V.F. (2010). Revising consensus in portal hypertension: report of the Baveno $V$ consensus workshop on methodology of diagnosis and therapy in portal hypertension. J. Hepatol., 53, 4, 762-768.

4. Paravecino, M., Chun, I.S., \& Madoff, D.C. (2009). Major hepatic resection for hepatocellular carcinoma with or without portal vein embolization: Perioperutive outcome and survival. Surgery, 145, 4, 399-405.

5. Sawada, K., Ohtake, T., \& Veno, N. (2011). Multiple portal hypertensive polyps of the jejunum accompanied by anemia of the unknown origin. Gastrointest., Endosc., 73, 179-182.

6. Hnatiuk, M.S., Tatarchuk, L.V., \& Yasinovskyi, O.B. (2016). Morfometrychna otsinka osoblyvostei remode- liuvanniia struktur dvanadtsiatypaloi kyshky pry resektsii riznykh obiemiv pechinky [Morphometric evaluation of the features of remodeling of duodenal structures during resection of different volumes of the liver]. Naukovyi visnyk Uzhhorodskoho universytetu. Seriia "Medytsyna" Scientific Journal of Uzhhorod University. Series "Medicine", 1 (49), 3-5 [in Ukrainian].

7. (2003). Zahalni etychni pryntsypy eksperymentiv na tvarynakh [General ethical principles of experiments on animal]. Endokrynolohiia - Endokrinology, 8, 1, 142145 [in Ukrainian].

8. Stalnaya, I.D., \& Garishvili, T.G. (1977). Metod opredeleniya malonovogo aldegida s pomoshchyu tiobarbiturovoy kisloty [The method of determination of malonic aldehyde with tiobarbituric acid]. Sovremennyye metody v biokhimii - Modern Methods in Biochemistry. Moscow: Meditsina [in Russian].

9. Meshchyken, I.F. (1988). Metod vyznachennia okysliuvalnoi modyfikatsii bilkiv plazmy (syrovatky) krovi [The method of determination of oxidative modification of plasma proteins (serum)]. Bukov. Med. Visnyk Bukovyna Medical Journal, 1, 156-157 [in Ukrainian].

10. Archakov, A.I., \& Mikhosoyev, I.M. (1998). Modifikatsiya belkov aktivnym kislorodom i ikh raspad 
[Modification of proteins by active oxygen and their decay]. Biokhimiya - Biochemistry, 54, 2, 179-186 [in Ukrainian].

11. Koryakina, Ye.V., \& Belov, S.V. (2004). Molekuly sredney massy kak integralnyy pokazatel metabolicheskikh narusheniy [Molecules of the average mass as an integral index of metabolic disturbances]. Klin. i lab. diagnostika Clinical and Laboratory Diagnostics, 3, 3-8 [in Russian].

12. Sorochinnikov, A.G., \& Dorosevich, A.Ye. (2007). Gistologicheskaya i mikroskopicheskaya tiekhnika [Histological and microscopic equipments]. Moscow: Meditsina [in Russian].

13. Avtadnilov, G.G. (2002). Osnovy kolichestvennoy patologicheskoy anatomii [Basis of quantitative pathological anatomy]. Moscow: Meditsina [in Russian].
14. Lapach, S.N., Gubenko, A.V., \& Babich, P.N. (2001). Statistichieskiye metody v miediko-biologicheskikh issledovaniyakh Excell [Statistical methods in medicobiological investigation Excell]. Kyiv: Morion [in Ukrainian].

15. Lisnianskyi, N.V. (2017). Rol oksydatyvnoho stresa $v$ patohenezi khronichnoho enterokolita na foni eksperymentalnoho streptozototsynovoho diabeta [The role of oxidative stress in the pathogenesis of chronic enterocolitis at experimental streptosotocin diabetes]. Medychna i klinichna khimiia - Medical and Clinical Chemistry, 19, 1, 53-57 [in Ukrainian].

А. Г. Шульгай, Л. В. Татарчук, М. С. Гнатюк ТЕРНОПОЛЬСКИЙ ГОСУДАРСТВЕННЫЙ МЕДИЦИНСКИЙ УНИВЕРСИТЕТ ИМЕНИ И. Я. ГОРБАЧЕВСКОГО

\section{ЭНДОГЕННАЯ ИНТОКСИКАЦИЯ ОРГАНИЗМА ПОДОПЫТНЫХ ЖИВОТНЫХ ПРИ ПОРАЖЕНИИ ТОЩЕЙ КИШКИ В УСЛОВИЯХ ПОСТРЕЗЕКЦИОННОЙ ПОРТАЛЬНОЙ ГИПЕРТЕНЗИИ}

\section{Резюме}

Вступление. Удаление больших объемов паренхимы печени может сопровождаться возникновением пострезекционной портальной гипертензии. Последняя приводит к морфологической перестройке органов бассейна воротной печеночной вены, поражению их структур, возрастанию эндогенной интоксикации, которая при повреждениях тощей кишки в названных патологических условиях исследована недостаточно.

Цель исследования - изучить особенности эндогенной интоксикации организма подопытных животных при поражении тощей кишки в условиях пострезекционной портальной гипертензии.

Методы исследования. Исследования проведены на 60 белых крысах-самцах, которых разделили на 4 группы: 1-я насчитывала 15 интактных животных; 2-я - 15 крыс, у которых было удалено 31,5\% паренхимы печени; 3-я - 15 животных, у которых удалили 42 \% паренхимы печени; 4-я - 15 крыс после резекции 58,1 \% паренхимы печени. Эвтаназию подопытных животных осуществляли путем кровопускания в условиях тиопенталового наркоза через месяц после начала эксперимента. Состояние эндогенной интоксикации оценивали по концентрации в сыроватке крови ТБК-активных продуктов, определению окислительной модификации белков, содержанию молекул средней массы. Гистологические препараты с тощей кишки окрашивали гематоксилин-эозином, по ван-Гизон, Маллори, Вейгерту, толуидиновым синим. Гистостереометрически определяли относительные объемы поврежденных эпителиоцитов, мышечных клеток, эндотелиоцитов. Количественные величины обрабатывали статистически.

Результаты и обсуждение. У крыс через месяц после резекции 42 и 58,1 \% паренхимы печени наблюдали расширение печеночной воротной вены, полнокровие и расширение брыжеечных вен и видимого венозного русла тонкой и толстой кишок. Выявленные изменения свидетельствовали о наличии портальной гипертензии. Слизистая оболочка тощей кишки полнокровная, отечная, с редкими очагами точечных кровоизлияний. В стенке тощей кишки обнаружили дистрофрию, некробиоз эпителиоцитов, миоцитов, эндотелиоцитов, стромальных структур, инфильтративные и склеротические прочессы, которые были более выражены при резекции 58,1 \% паренхимы печени. Относительные объемы поврежденных исследуемых структур значительно возрасли через месяц после резекции 42 \% паренхимы печени и наибольших величин достигли при удалении 58,1 \% объема данного органа, указывая на выраженное поражение тощей кишки в смоделированных экспериментальных условиях. При выявленном поражении тощей кишки существенно возрасла эндогенная интоксикация организма, что подтверждалось достоверным $(p<0,05)$ увеличением содержания молекул средней массы в сыворотке крови, ТБК-активных продуктов, окислительномодифицированных белков. Степень эндогенной интоксикации организма при пострезекционной портальной гипертензии зависела от выраженности поражения тощей кишки.

Выводы. Резекция больших объемов паренхимы печени приводит к развитию пострезекционной портальной гипертензии, повреждений структур тощей кишки и эндогенной интоксикации организма, 
которая сопровождается увеличением содержания молекул средней массы, окислительномодифицированных белков, активацией перекисного окисления липидов. Степень эндогенной интоксикации организма зависит от удаленного объема паренхимы печени и выраженности повреждений структур тощей кишки.

КЛЮЧЕВЫЕ СЛОВА: эндогенная интоксикация; тощая кишка; пострезекционная портальная гипертензия.

A. G. Shulgay, L. V. Tatarchuk, M. S. Hnatjuk

I. HORBACHEVSKY TERNOPIL STATE MEDICAL UNIVERSITY

\title{
THE ENDOGENOUS INTOXICATION IN THE ORGANISM OF EXPERIMENTAL ANIMALS AT JEJUNUM DAMAGE IN CONDITIONS OF POSTRESECTION PORTAL HYPERTENSION
}

\begin{abstract}
Summary
Introduction. Removal of large volumes of liver parenchyma is complicated by postresection portal hypertension. The latter leads to a morphological rearrangement of the organs of the portal hepatic vein, the damage to their structures, and the growth of endogenous intoxication, which is not sufficiently investigated in the case at jejunum damage at these pathological conditions.
\end{abstract}

The aim of the study - to learn the characteristics of endogenous intoxication of the experimental animals in the case of damage of the jejunum in conditions of postresection portal hypertension.

Research Methods. The studies were performed on 60 white male rats, which were divided into 4 groups. The first group consisted of 15 intact animals, 2-15 rats, in which we removed $31.5 \%$ of liver parenchyma, 3-15 animals after resection $42 \%$ of liver parenchyma, 4-15 rats in which we removed 58,1\% liver parenchyma. One month after beginning of the experiment euthanasia of experimental animals was performed by bloodletting under conditions of thiopental anesthesia. The state of endogenous intoxication by the concentration of TBC-active products, oxidative modification of proteins, and the content of molecules of the average mass were determined. Histologic section from the jejunum stained with hematoxylin-eosin, for van Giason, Mallory, Weigert, and toluidine blue. Histostereometrically, the relative volumes of damaged epithelial cells, muscle cells, and endothelial cells were determined. Quantitative values were processed statistically.

Results and Discussion. In rats, one month after resection, $42 \%$ and $58.1 \%$ of the liver parenchyma, enlargement of the hepatic portal vein, enlargement of the mesenteric veins and the visible venous bed of the small and large intestines were observed. The evidence of the presence of portal hypertension is detected. Mucous membrane of the jejunum is full-blooded, edematous, with single cells of point hemorrhages. In the wall of the jejunum we revealed dystrophy, necrobiosis of epithelial cells, myocytes, endothelial cells, stromal structures, infiltrative and sclerotic processes, which were more pronounced during resection of $58.1 \%$ of liver parenchyma. Relative volumes of damaged investigated structures increased significantly month after resection of $42 \%$ of liver parenchyma and the largest values they reached when removed $58.1 \%$ of the volume of this organ, indicating a significant defeat of the jejunum under simulated experimental conditions. In the case of the detected lesions of the jejunum, endogenous intoxication of the body was expressed, which was confirmed by a significant $(p<0.05)$ increase in the content of molecules of the average mass in serum, TBK-active products, oxidative modification of proteins. The degree of endogenous intoxication of the body at postresection portal hypertension depended on the severity of the damage of the jejunum.

Conclusions. Resection of large volumes of liver parenchyma leads to the development of postresection portal hypertension, damage structures of the jejunum and endogenous intoxication of the body, which is accompanied by an increase in the content molecules of the average mass, the oxidative modification of proteins, the activation of peroxidation of lipids. The degree of endogenous intoxication of the body depends on the removed volume of liver parenchyma and the severity of damage the structures of the jejunum.

KEY WORDS: endogenous intoxication; jejunum; postresection portal hypertension.

Отримано 31.05.18

Адреса для листування: М. С. Гнатюк, Тернопільський державний медичний університет імені І. Я. Горбачевського, майдан Волі, 1, Тернопіль, 46001, Україна, e-mail: hnatjuk@tdmu.edu.ua. 